\title{
GEOPHYSICAL AND HYDRO-CHEMICAL INVESTIGATION OF THE AREA AROUND A WASTE DUMP SITE IN ILE-IFE, SOUTHWEST NIGERIA
}

\author{
K. O. OBASE, M. O. OLORUNFEMI, and J. O. AKINTORINWA
}

(Received 15 August, 2008; Revision Accepted 12 January, 2009)

\begin{abstract}
An integrated geophysical and hydro-chemical investigation was carried out in the area around the StadiumApollo Market waste dump located in Igboya area of lle-Ife. It was with the aim of determining the geoelectric characteristics and groundwater chemistry which were used in delineating the subsurface sequence and evaluating the possible pollution of groundwater in the area. Eight Vertical Electrical Sounding (VES) stations were occupied along two traverse lines trending North-South and East-West directions. Dipole-Dipole profilings were also carried out along same traverses. Eight water samples were collected from hand dug wells and analyzed for some chemical elements such as total acidity, major ions $\left(\mathrm{Na}^{+}, \mathrm{K}^{+}, \mathrm{Cl}^{-}, \mathrm{Mg}^{2+}, \mathrm{Ca}^{2+}\right), \mathrm{NO}_{3}{ }^{-}$and heavy metals $(\mathrm{Cd}, \mathrm{Cu}, \mathrm{Fe}, \mathrm{Hg}$, and $\mathrm{Pb})$. Results of the investigation indicate that a maximum of four subsurface layers- the top soil, clay/sandy clay unit, the weathered layer and the basement bedrock exist in the area. The weathered layer constitutes the main aquifer unit with thicknesses of between 7 and $38 \mathrm{~m}$. From the 2-D resistivity structures, contaminant plumes characterized by relatively low resistivity values $(<150 \mathrm{ohm}-\mathrm{m})$ were identified down to depth of about $40 \mathrm{~m}$ in some places. Hydrochemical results showed that the total acidity and concentration of $\mathrm{Na}^{+} \mathrm{Cl}^{-}$and heavy metals $(\mathrm{Cd}, \mathrm{Cu}, \mathrm{Fe}, \mathrm{Hg}$ and $\mathrm{Pb})$ in wells closest to and down slope of the waste dump (total acidity $5.1-10.0 \mathrm{mg} / \mathrm{l} ; \mathrm{Na}^{+} 8.92-11.07 \mathrm{mg}^{-} / \mathrm{Cl}^{-} 127.62-$ $297.78 \mathrm{mg} / \mathrm{l} ; \mathrm{Cd}, 0.006-0.009 \mathrm{mg} / \mathrm{l} ; \mathrm{Cu}, 0.330-1.840 \mathrm{mg} / \mathrm{l} ; \mathrm{Fe}, 2.300-4.600 \mathrm{mg} / \mathrm{l} ; \mathrm{Hg}, 1.247 \mathrm{mg} / \mathrm{l}$ and Pb, $0.260 \mathrm{Mg} / \mathrm{l})$ are higher than concentrations in distant wells, and most of them $\left(\mathrm{Cl}^{-}, \mathrm{Cd}, \mathrm{Cu}, \mathrm{Fe}, \mathrm{Hg}\right.$, and $\left.\mathrm{Pb}\right)$ exceeded national and international drinking water quality standards. It can be concluded that the groundwater in the area had been contaminated and the plume had migrated to a significant depth
\end{abstract}

KEYWORDS: Geophysical, Hydro-chemical, Waste Dump, Groundwater Quality, Pollution

\section{INTRODUCTION}

One of the common ways of waste disposal is by open dump. The primary consequence of solid waste disposal in open dump is the potential for gas and leachate generation due mainly to microbial decomposition of the waste materials. The migration of gas and leachate away from the waste dump and subsequent release into the surrounding environment, especially groundwater presents serious environmental problems including health hazard (Adepelumi et al., 2001, Tijani, et al., 2002, Samanjara and Bandara, 2003).

The Stadium-Apollo Market waste dump is located along Ife Township Stadium road off Obafemi Awolowo University Road 7 in Igboya area of Ile-Ife, Osun State. It is an active dump site that has been receiving a mix of solid wastes from within and around the neighborhood for over 30 years. The nature of waste mix disposed in the dump is heterogeneous and widely varied. Wastes such as garbage. (Waste fruits, meat, vegetables etc.); rubbish (paper, wood, scrap, rubber, plastic, nylon, leather, metals, glass, ceramics, aerosol cans and other house hold wastes); pathological waste (human and animal wastes, dead animals, hospital waste etc.); industrial wastes such as chemicals, waste batteries from mechanic workshops, damaged electrical appliances, vehicles spare parts and agricultural wastes (farm animal manure, crop residue animal dung etc) are visible in the waste dump site.

The inhabitants of Igboya area and environs depend mainly on groundwater from wells to meet most of their daily water needs. Since these wells are generally shallow and located within the vicinity of the waste dump, there is the possibility that the groundwater in the area may have been contaminated through leachate percolation. Meanwhile, there have been reported cases of impure/coloured water from wells closest to the dump site. This study therefore intends to establish the extent of the contamination within and around the study area, identify the aquifer unit(s) and ascertain the presence of contaminant plumes within the subsurface. It also intends to determine specific contaminants through hydro-chemical analysis of sampled water and also determine the direction of contaminant migration.

K. O. Obase, Institute of Ecology and Environmental Studies

M. O. Olorunfemi, Department of Geology, Obafemi Awolowo University, lle-Ife, Nigeria.

J. O. Akintorinwa, Department of Applied Geophysics, Federal University of Technology, Akure, Nigeria.

Editor's Note: This paper was earlier published in volume 7 (1) 2009. It is being repubished here because of figure 5 and 6 which were printed in black and white 


\section{THE GEOLOGY OF THE AREA}

The Ife-llesha area, which encompasses the present study area, is underlain by the Precambrian Basement Complex rocks of Southwestern Nigeria. Detailed descriptions of the geology of the area had been given by various workers including Elueze (1981), Ajayi (1981), Klemm et al (1988), Ige (1988) and Rahaman (1988).
According to Ige and Asubiojo (1991), rocks of Ife-llesha area include the gneisses, granites, amphibolites, schists and pegmatites (Fig 1). The local geology of the project site is schist. The rocks have generally undergone different degrees of weathering (Rahaman, 1998).

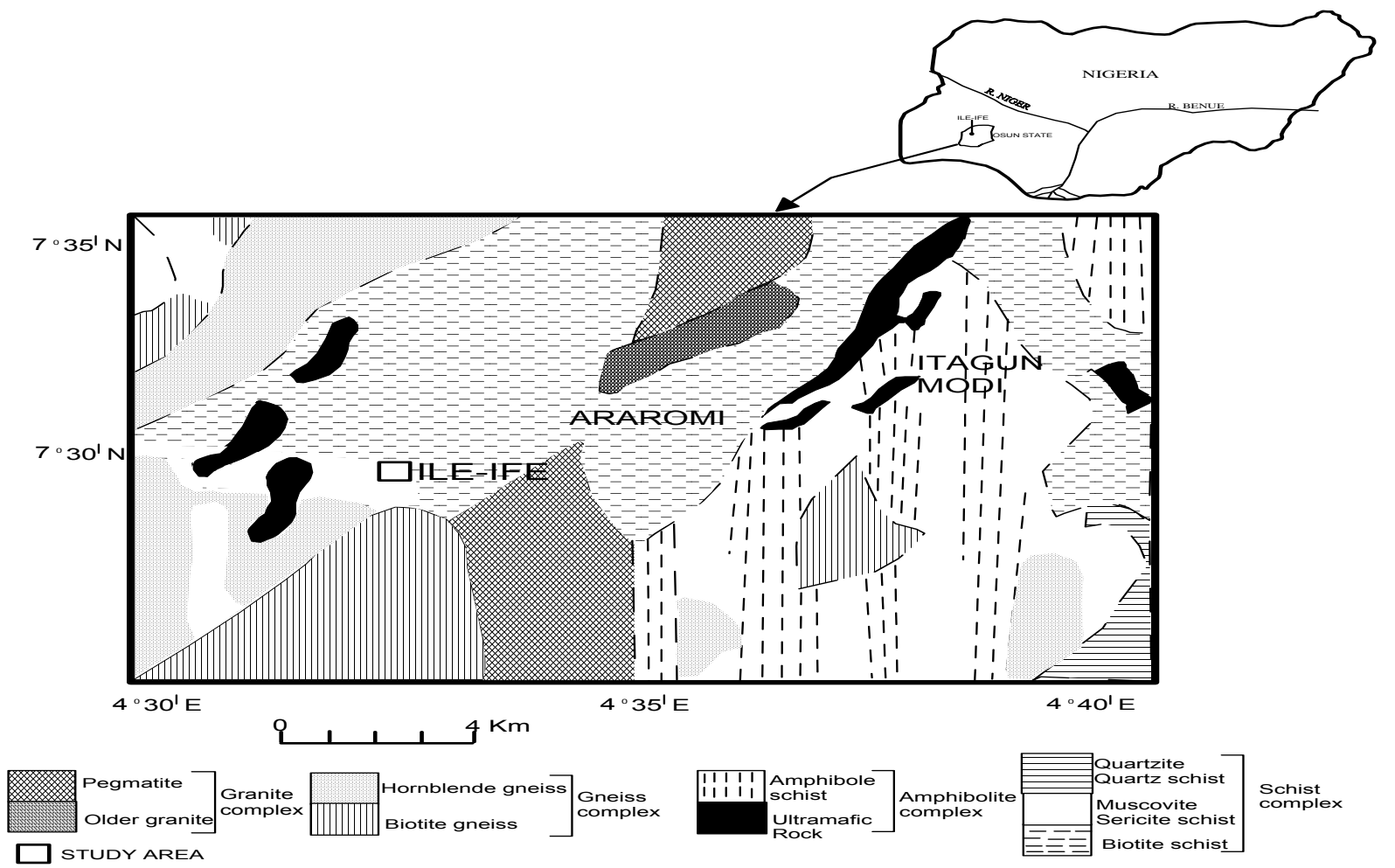

FIG. 1: GEOLOGICAL MAP OF THE AREA AROUND ILE-IFE (MODIFIED AFTER ELUEZE, 1981 AND IGE, 1988)

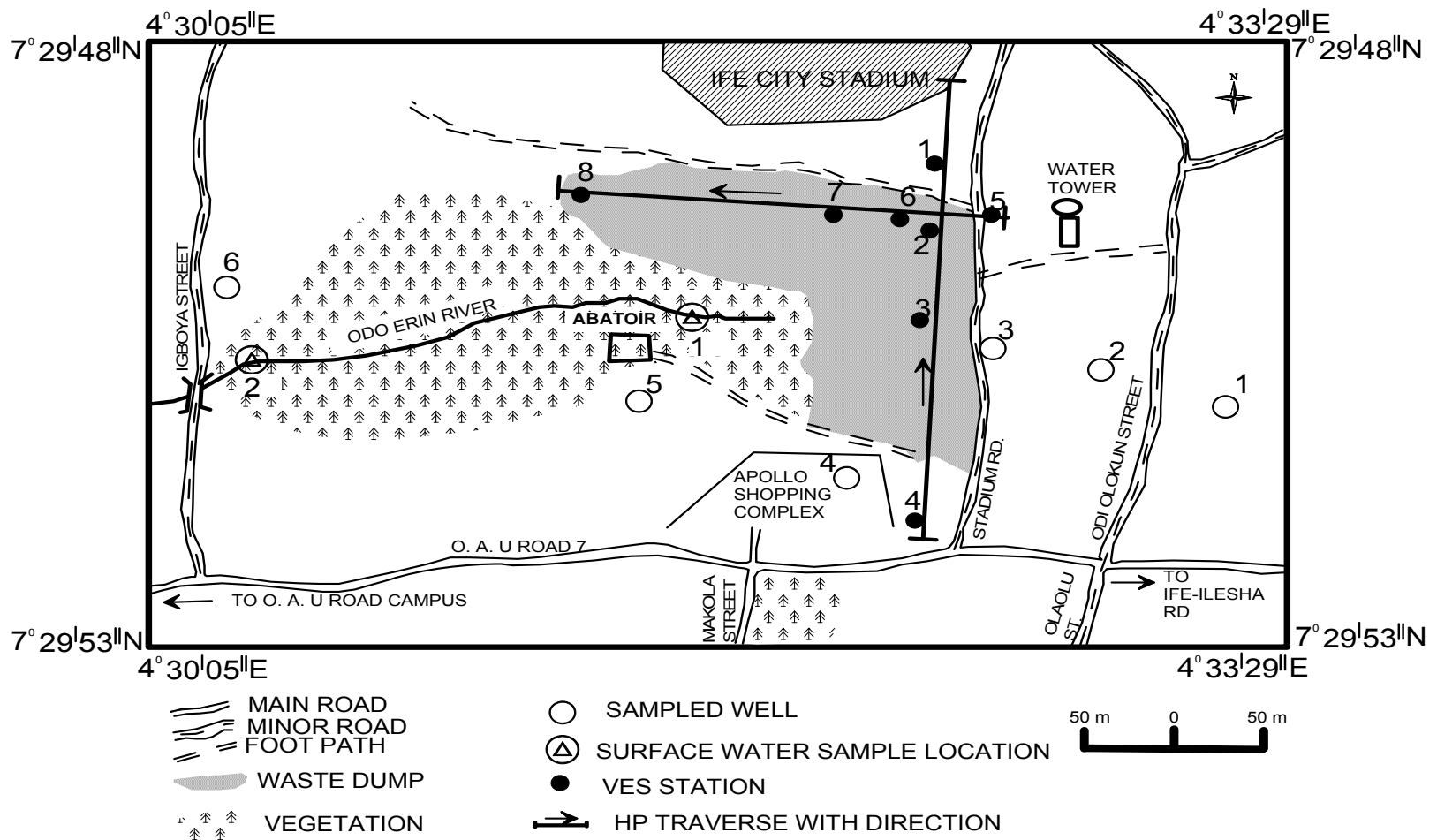

FIG. 2: MAP OF THE STUDY AREA SHOWING THE DUMP SITE 


\section{METHODS OF STUDY}

The study involved geophysical and hydrochemical investigations. The geophysical investigation involved the electrical resistivity method (Kearey and Brooks, 1988 and Bedient et al, 1998). The Vertical Electrical Sounding (VES) and the dipole-dipole profiling techniques were used in the study.

Eight Schlumberger VES stations were occupied along two traverses (Fig 2). The traverses trend approximately North-South and East-West. Measurements of ground resistance were made with the ABEM Terameter SAS 300C Resistivity Meter. The VES data were interpreted quantitatively by partial curve matching technique. The multi-layered field curves were interpreted segment-by-segment using theoretically generated master curves and associated auxiliary curves. The interpretation results from partial curve matching were used as started model parameters in 1-D forward modeling involving RESIST version 1.0 software. The final interpretation results were used to prepare geoelectric sections (Figs. 3 and 4 ).
Dipole-Dipole profiling was carried out along the two traverses. The inter-electrode spacing of $10 \mathrm{~m}$ was used while the expansion factor, $n$, was varied from 1-5. The dipole-dipole data were inverted to 2-D resistivity structures (Figs 5 and 6) using Diprro Version 4.01 software developed by Junk Ho Kim (1999-2001).

The hydro-chemical analysis involved the collection and analysis of water samples for chemical analysis. Eight water samples; three samples from wells in the up slope direction and three from wells in the down slope direction and the other two water samples were also collected from a nearby Odo Eran River. Sampling was done during the dry season. This was to ensure a true reflection of the quality of the groundwater, as there would be dilution due to rainfall or infiltration of surface run-off into the wells during the rainy season. The most remote wells (wells 1 and 6) (Fig 2) served as control wells. The study locations, including co-ordinates and water levels are presented in Table 1. The methods used for the analyses of the different parameters are summarized in Table 2.

Table 1: General Information on Water Sample Locations and Well Water Levels.

\begin{tabular}{|l|l|l|l|l|l|}
\hline Sample Description & \multicolumn{1}{|c|}{$\begin{array}{c}\text { Longitude } \\
(\mathrm{E})\end{array}$} & \multicolumn{1}{|c|}{$\begin{array}{c}\text { Latitude } \\
(\mathrm{N})\end{array}$} & $\begin{array}{c}\text { Elevation } \\
(\mathrm{m}) \text { a. s. I. }\end{array}$ & $\begin{array}{c}\text { Distance from } \\
\text { dump site }\end{array}$ & $\begin{array}{l}\text { Static Water } \\
\text { Level }(\mathrm{m})\end{array}$ \\
\hline Well 1 & $004^{0} 33.333^{\prime \prime}$ & $07^{0} 29.612^{\prime \prime}$ & 286 & 150.0 & 8.2 \\
\hline Well 2 & $004^{0} 33.332$ & $07^{0} 29.659^{\prime \prime}$ & 285 & 83.0 & 6.2 \\
\hline Well 3 & $004^{0} 33.325^{\prime \prime}$ & $07^{\circ} 29.684^{\prime \prime}$ & 280 & 19.0 & 5.4 \\
\hline Well 4 & $004^{0} 33.272^{\prime \prime}$ & $07^{0} 29.688^{\prime \prime}$ & 278 & 55.0 & 8.0 \\
\hline Well 5 & $004^{0} 33.225^{\prime \prime}$ & $07^{\circ} 29.754^{\prime \prime}$ & 270 & 183.0 & 7.0 \\
\hline Well 6 Eran River & $004^{0} 33.191^{\prime \prime}$ & $07^{0} 29.891^{\prime \prime}$ & 268 & 421.0 & 3.6 \\
\hline $\begin{array}{l}\text { Odo } 33.239^{\prime \prime} \\
\text { location 1 }\end{array}$ & $07^{0} 29.792^{\prime \prime}$ & 267 & 141.0 & - \\
\hline $\begin{array}{l}\text { Odo Eran River } \\
\text { location 2 }\end{array}$ & $004^{0} 33.173^{\prime \prime}$ & $07^{0} 29.859^{\prime \prime}$ & 264 & 408.0 & - \\
\hline
\end{tabular}

a. s. I.: Above Sea Level

Table 2: Methods used in Measuring the Different Chemical Parameters.

\begin{tabular}{|l|l|}
\hline \multicolumn{1}{|c|}{ Parameters } & Test methods \\
\hline Total Acidity & KCL extraction / Titrimetric Method \\
\hline Nitrate & Disulfuric Acid Method \\
\hline Potassium ion & Flame Photometry Method \\
\hline Sodium ion & Flame Photometry Method \\
\hline Magnesium ion & Atomic Absorption Spectrophytometry Method \\
\hline Calcium ion & Atomic Absorption Spectrophytometry Method \\
\hline Chloride & Silver Nitrate Method \\
\hline Heavy metals $(\mathrm{Cd}, \mathrm{Cu}, \mathrm{Fe}, \mathrm{Hg}$ and $\mathrm{Pb})$ & Atomic Absorption Spectrophytometry Method \\
\hline
\end{tabular}

Each determination was based on standard methods of the American Public Health Association (APHA, 1992); Chemical Methods of the British Drug House (BDH, 1978) and methods for physical and chemical analysis of fresh waters.

\section{RESULTS AND DISCUSSIONS}

\section{Geoelectric Sections}

The VES interpretation results and the type curves are shown in Table 3. The VES curves are the
$\mathrm{HKH}, \mathrm{HA}, \mathrm{KH}$ and $\mathrm{QH}$ type. The dominant $\mathrm{KH}$ type curve constitutes half of the VES curves (Table 3). Four subsurface layers were identified. These include the topsoil, clay/sandy clay, the weathered layer and the fresh basement (Figs. 3 and 4). 


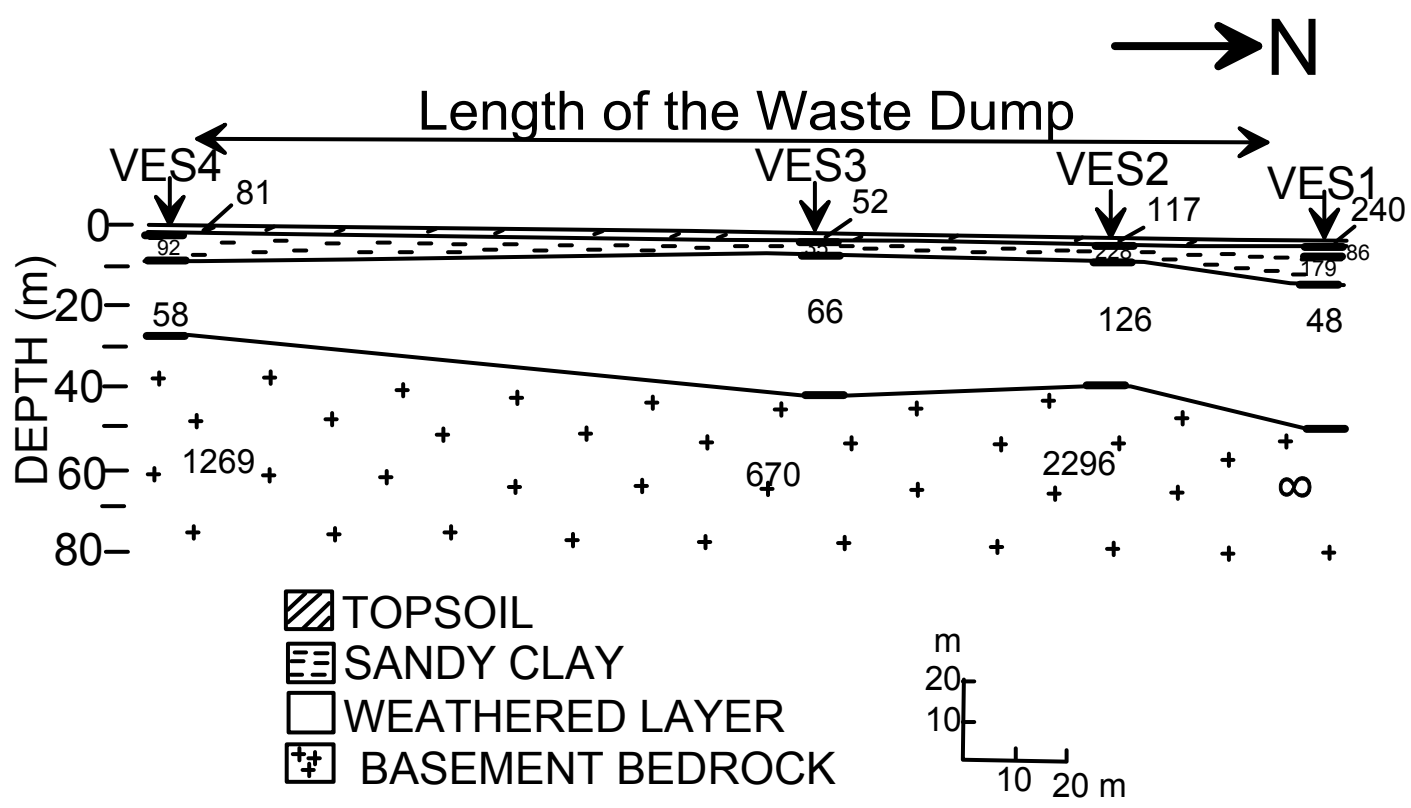

FIG. 3: GEOELECTRIC SECTION ALONG TRAVERSE 1: VES 1, 2, 3 AND 4
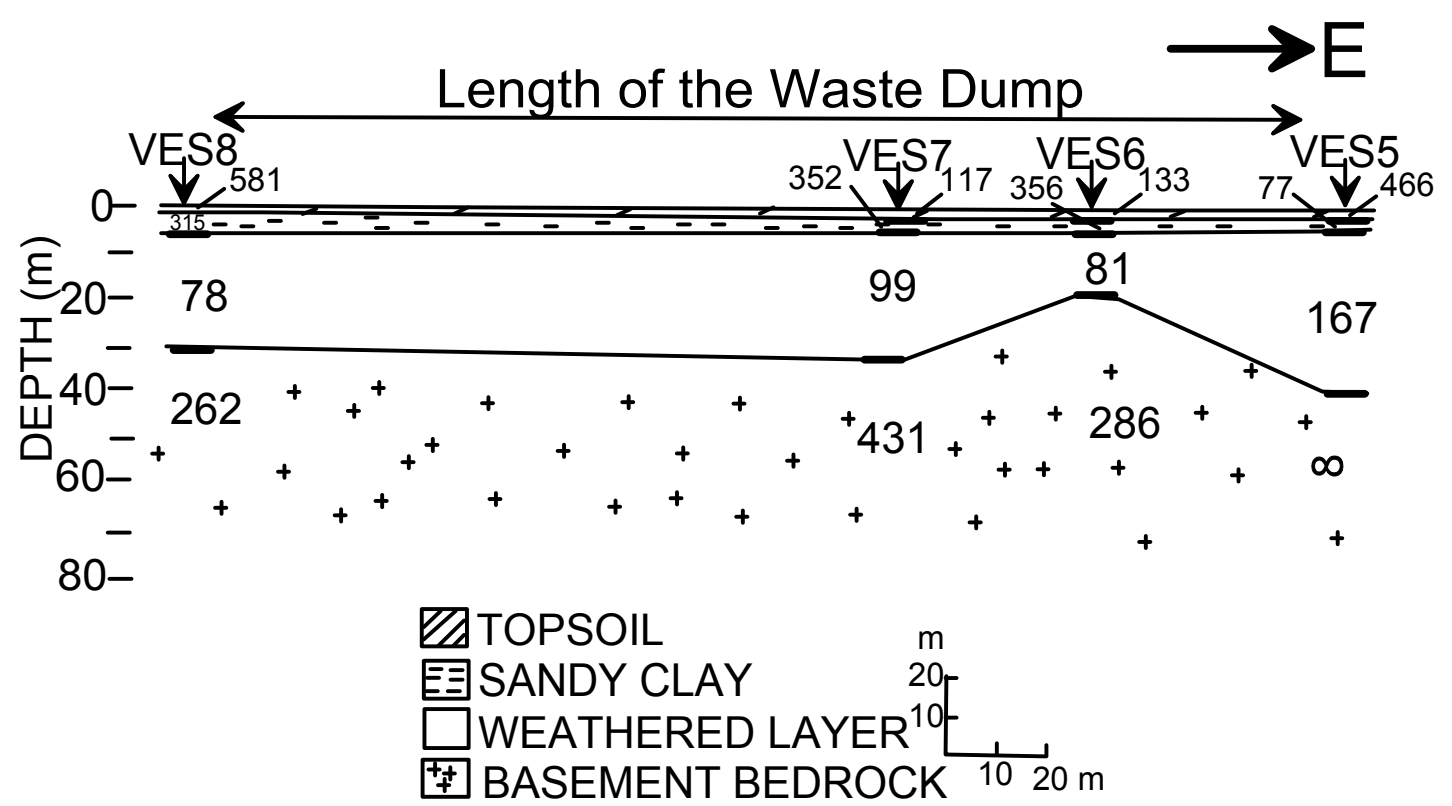

FIG. 4: GEOELECTRIC SECTION ALONG TRAVERSE 2: VES 5, 6, 7 AND 8

Table 3: VES Interpretation Results

\begin{tabular}{|l|l|l|l|l|}
\hline $\begin{array}{l}\text { VES } \\
\text { Stations }\end{array}$ & $\begin{array}{l}\text { Traverse } \\
\text { Lines }\end{array}$ & $\begin{array}{l}\text { Thickness }(\mathrm{m}) \mathrm{h}_{1} / \mathrm{h}_{2} / \mathrm{h}_{3^{--}} \\
-/ \mathrm{h}_{\mathrm{n}}\end{array}$ & $\begin{array}{l}\text { Resistivity } \\
\rho_{1} / \rho_{2} / \rho_{3} /---\rho_{\mathrm{n}}\end{array}$ & $\begin{array}{l}\text { Type } \\
\text { curves }\end{array}$ \\
\hline 1 & 1 & $1.7 / 1.3 / 7.5 / 36.9$ & $241 / 86 / 179 / 48 / \infty$ & $\mathrm{HKH}$ \\
\hline 2 & 1 & $0.6 / 4.2 / 4.0 / 30.2$ & $117 / 228 / 126 / 2296$ & $\mathrm{KH}$ \\
\hline 3 & 1 & $0.8 / 2.2 / 36.1$ & $52 / 35 / 66 / 670$ & $\mathrm{HA}$ \\
\hline 4 & 1 & $0.7 / 6.5 / 20.4$ & $81 / 92 / 58 / 1269$ & $\mathrm{KH}$ \\
\hline 5 & 2 & $0.3 / 2.4 / 36.0$ & $466 / 77 / 167 / \infty$ & $\mathrm{HA}$ \\
\hline 6 & 2 & $0.3 / 4.2 / 13.5$ & $132 / 356 / 81 / 286$ & $\mathrm{KH}$ \\
\hline 7 & 2 & $0.3 / 3.5 / 27.9$ & $117 / 352 / 99 / 431$ & $\mathrm{KH}$ \\
\hline 8 & 2 & $0.2 / 4.8 / 24.0$ & $581 / 315 / 78 / 262$ & $\mathrm{QH}$ \\
\hline
\end{tabular}

The topsoil has layer resistivity and thickness ranging from 52-581 ohm-m and 0.2-1.7 $\mathrm{m}$, respectively. The $2.2-7.5 \mathrm{~m}$ thick clay/sandy clay layer has layer resistivity ranging from $35-365 \mathrm{ohm}-\mathrm{m}$. The weathered layer resistivities and thicknesses are in the range of 42-167 ohm-m and 13.5-36.5 m respectively. The basement bedrock has layer resistivity of $262-\infty$ ohm-m (Figs. 3 and 4). Depth to the basement bedrock 
varies from 27.6-46.4 $\mathrm{m}$. The weathered basement constitutes the main aquifer unit. All hand dug wells around the study area exploit groundwater from this aquiferous unit.

\section{Dipole - Dipole Sections}

The 2-D resistivity structures obtained from the inversion of the dipole-dipole data are shown in Figures 5 and 6 . The resistivity structure along Traverse 1 shows resistivity values that range from 14-3131 ohm-m, (Fig 5 (iii)). Low resistivity zones ( $\angle 150$ ohm-m in green colours) with significant depth extent of up to $40 \mathrm{~m}$, suspected to be leachate impacted zones, are found between distances 50 and $80 \mathrm{~m} ; 130$ and $160 \mathrm{~m}$ and 185 and $200 \mathrm{~m}$. These areas correlate with the actual location of the waste dump which lies between distances 47 and $206 \mathrm{~m}$ along the traverse (see Fig 2). The resistivity structure along Traverse 2 revealed marked variation in subsurface resistivity across the traverse. The resistivity values range from $19-2364$ ohm-m, (Fig 6 (iii)). The section shows areas with high and low resistivity values.

(i)

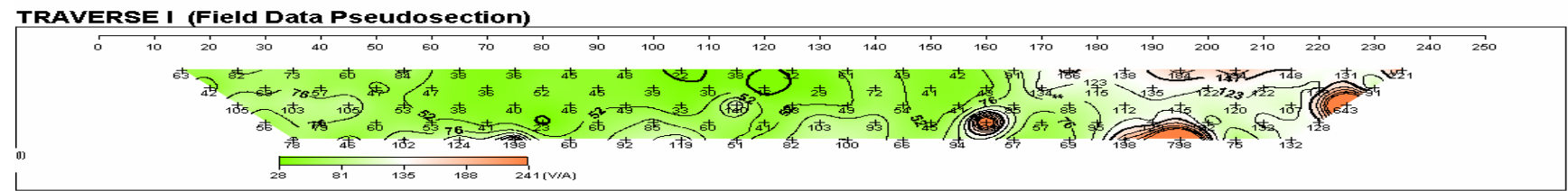

(ii)

TRAVERSE I (Theoretical Data Pseudosection)

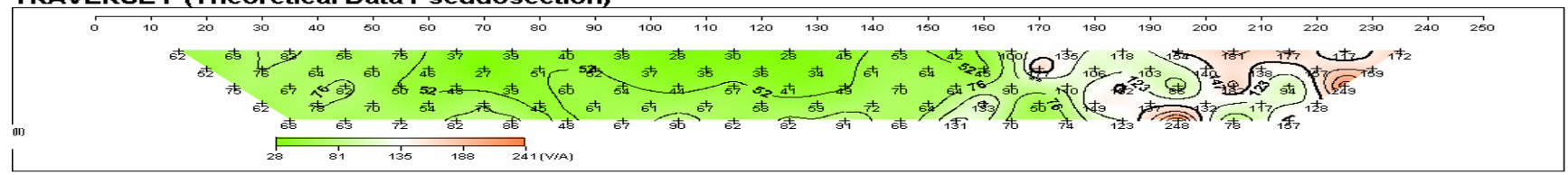

(iii)

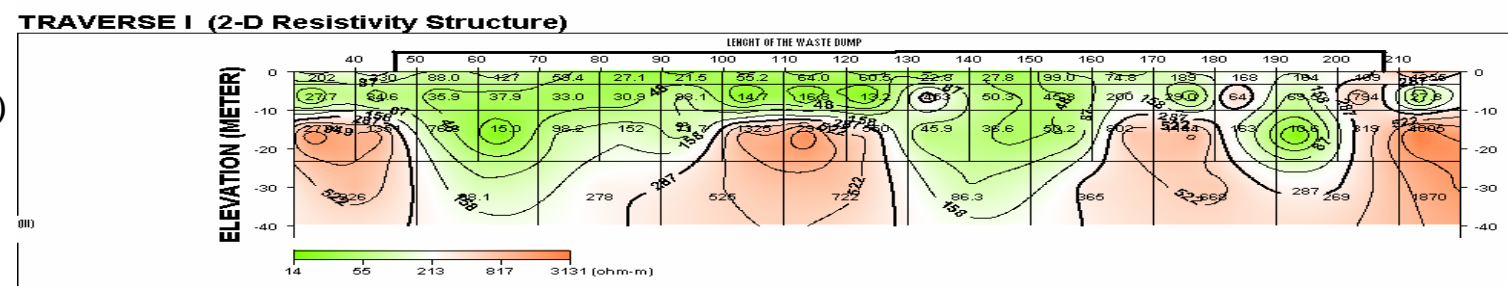

Fig 5: Dipole-Dipole Section along Traverse I - Stadium-Apollo Market Waste Dump Investigation (i) Field Data Pseudosection (ii) Theoretical Pseudosection (iii) 2-D Resistivity Structure

(i)

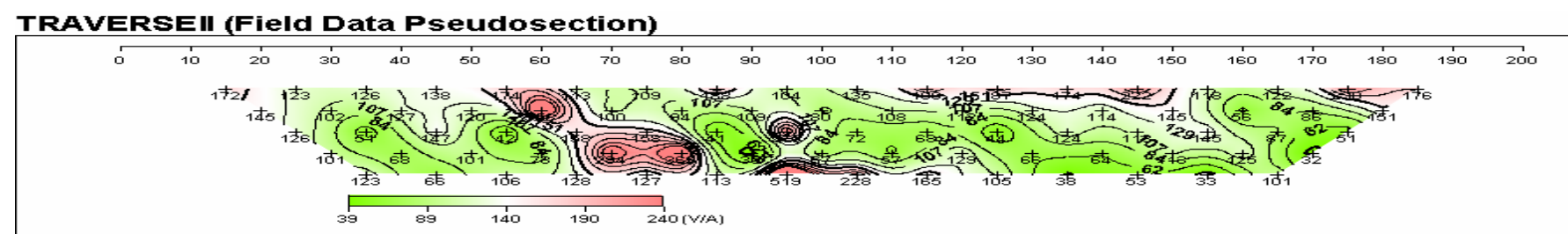

\section{TRAVERSEII (Theoretical Data Pseudosection)}

(ii)

(20 10 20

\section{TRAVERSEII (2-D Resistivity Structure)}

(iii)

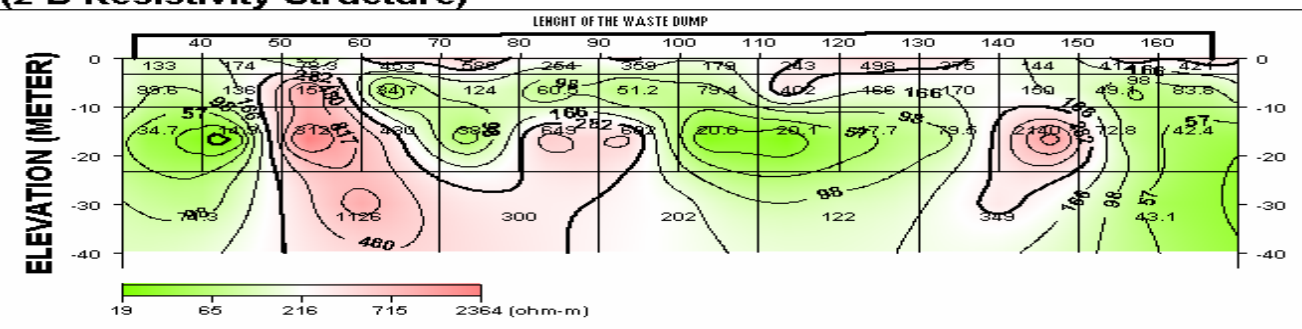

Fig 6: Dipole-dipole Section along Traverse II- Stadium-Apollo Market Waste Dump Investigation (i) Field Data Pseudosection (ii) Theoretical Pseudosection (iii) 2-D Resistivity Structure.

Areas with low resistivity values (< $150 \mathrm{ohm}-\mathrm{m}$ in green colours) are indicative of a conducting medium suspected to have been impacted. The low resistivity zones are between distances 1-46 m; 60-135 m and
150-170 m. The depth extent varies from $20 \mathrm{~m}$ to more than $40 \mathrm{~m}$, particularly between distances 0 and $45 \mathrm{~m}$; 110 and $140 \mathrm{~m}$; and 150 and $170 \mathrm{~m}$ where leachate from the waste dump is suspected. 
Based on field observations and 2-D resistivity structures obtained from the inverted dipole-dipole data, it can be inferred that:

i. The subsurface in the study area is suspected to have been impacted by leachate from the waste dump;

ii Suspected impacted zones are characterized by relatively low resistivity $(\angle 150 \mathrm{ohm}-\mathrm{m})$ and

iii

There has been a vertical movement of the leachate down to depths of about $40 \mathrm{~m}$.

\section{Hydro-Chemical Analysis}

Results of hydro-chemical analysis are presented in Tables 4 and 5 . The results show that wells closest to the waste dump and those located down slope of the waste dump have higher concentrations of the analyzed parameters.

Total acidity values were highest $(10 \mathrm{mg} / \mathrm{l})$ in well 3 ( $20 \mathrm{~m}$ from the dump). Well 6 which is located 430 $\mathrm{m}$ from the waste dump has the lowest value $(2.5 \mathrm{mg} / \mathrm{l})$ of total acidity (Table 4). The results of total acidity showed that the closer the well to the dump, the higher is the value of total acidity. Waste batteries from mechanic workshops and from household that are disposed in the waste dump are suspected to be the source of total acidity in the groundwater of the area.

$\mathrm{Na}^{+}$, like total acidity, showed a gradual decrease in concentration with increasing distance of sampled wells away from the waste dump (Table 4).
Wells 3 (20 m up slope) and 4 (55 m down slope) are the closest to the dump and their concentration values for $\mathrm{Na}^{+}$are $10.7 \mathrm{mg} / \mathrm{l}$ and $11.07 \mathrm{mg} / \mathrm{l}$ respectively (Table 4). The least values of $\mathrm{Na}^{+}$(3.01 and $\left.2.85 \mathrm{mg} / \mathrm{l}\right)$ were detected in wells 1 and 6 respectively. These are control wells located further away $(160 \mathrm{~m}$ and $430 \mathrm{~m})$ from the. Human and animal wastes and decomposition of various minerals are the major contributors of $\mathrm{Na}^{+}$in groundwater (USGS, 2005).

The concentrations of $\mathrm{K}^{+}$were higher in wells 4 and $5(3.05 \mathrm{mg} / \mathrm{l}$ and $2.63 \mathrm{mg} / \mathrm{l}$ respectively), (Table 4$)$. The concentrations of $\mathrm{K}^{+}$in other wells are low (1.58$2.01 \mathrm{mg} / \mathrm{l}$ ) and could represent background values. Usually, $\mathrm{K}^{+}$in the environment is derived from potash salts and mines (Scoth and Smith, 1981).

The concentrations of $\mathrm{NO}_{3}^{-}$(Table 4) are higher in wells $3(1.80 \mathrm{mg} / \mathrm{l})$, well $6(1.02 \mathrm{mg} / \mathrm{l})$ and in surface water samples 1 and 2 (141 m and $403 \mathrm{~m}$ respectively down slope), compared to values detected in other wells (Table 4). The lowest values of $\mathrm{NO}_{3}{ }^{-}(0.20-0.60 \mathrm{mg} / \mathrm{l})$ are detected in wells $1,2,4$ and $5 . \mathrm{A} \mathrm{NO}_{3}{ }^{-}$concentration of less than $0.2 \mathrm{mg} / \mathrm{l}$ represents natural conditions while values greater than $3 \mathrm{mg} / \mathrm{l}$ may indicate human effects. $\mathrm{NO}_{3}{ }^{-}$concentration has not exceeded the maximum contaminant level (m. c. I) set by WHO (2004), FEPA (1991) and USGS (2002). Animal and human wastes, sewage systems garden fertilizer and livestock facilities are major contributors of $\mathrm{NO}_{3}^{-}$to groundwater but the largest share comes from society's wastes.

Table 4: Total Acidity, $\mathrm{Na}^{+}, \mathrm{K}^{+}, \mathrm{Cl}^{-}, \mathrm{NO}_{3}{ }^{-}$and Total Hardness in the Water

\begin{tabular}{|l|l|l|l|l|l|l|l|l|}
\hline $\begin{array}{l}\text { Up } \\
\text { slope }\end{array}$ & $\begin{array}{l}\text { Sample } \\
\text { description }\end{array}$ & $\begin{array}{l}\text { Total } \\
\text { Acidity } \\
(\mathrm{mg} / \mathrm{l})\end{array}$ & $\begin{array}{l}\mathrm{Na}^{+} \\
(\mathrm{mg} / \mathrm{l})\end{array}$ & $\begin{array}{l}\mathrm{K}^{+} \\
(\mathrm{mg} / \mathrm{l})\end{array}$ & $\begin{array}{l}\mathrm{Cl}^{-} \\
(\mathrm{mg} / \mathrm{l})\end{array}$ & $\begin{array}{l}\mathrm{NO}_{3}^{-} \\
(\mathrm{mg} / \mathrm{l})\end{array}$ & $\begin{array}{l}\text { Total } \\
\text { Hardness } \\
(\mathrm{mg} / \mathrm{l})\end{array}$ & $\begin{array}{l}\text { Distance } \\
\text { from dump } \\
\text { site }(\mathrm{m})\end{array}$ \\
\cline { 2 - 10 } & Well 1 & 3.0 & 3.01 & 1.58 & 113.44 & 0.20 & 49.7 & 160.0 \\
\cline { 2 - 9 } & Well 2 & 5.0 & 8.92 & 2.01 & 184.34 & 0.22 & 54.8 & 82.5 \\
\cline { 2 - 9 } & Well 3 & 10.0 & 10.71 & 1.69 & 297.78 & 1.80 & 50.4 & 20.0 \\
\hline \multirow{7}{7}{$\begin{array}{l}\text { Waste dump } \\
\text { slope }\end{array}$} & Well 4 & 3.4 & 11.07 & 3.05 & 127.62 & 0.26 & 61.7 & 55.0 \\
\cline { 2 - 9 } & Well 5 & 5.1 & 9.06 & 2.63 & 255.24 & 0.60 & 18.1 & 180.0 \\
\cline { 2 - 9 } & Well 6 & 2.5 & 2.85 & 1.72 & 113.44 & 1.02 & 16.2 & 430.0 \\
\cline { 2 - 9 } & $\begin{array}{l}\text { Surface } \\
\text { water } \\
\text { location 1 }\end{array}$ & 4.4 & 3.72 & 1.88 & 85.08 & 1.70 & 25.7 & 141.0 \\
\cline { 2 - 9 } & $\begin{array}{l}\text { Surface } \\
\text { water } \\
\text { location 2 }\end{array}$ & 3.4 & 4.05 & 1.99 & 170.16 & 1.89 & 19.7 & 403.0 \\
\hline
\end{tabular}

Groundwater in the study area belongs to the soft water category (0-60 mg/l of $\left.\mathrm{CaCO}_{3}\right)$. However, well 4, located $55 \mathrm{~m}$ down slope from the waste dump and within the Apollo Market Complex displays moderate hardness $\left(61-120 \mathrm{mg} / \mathrm{l}\right.$ of $\left.\mathrm{CaCO}_{3}\right)$. Hardness of water results from dissolution of metallic ions in water, dissolved limestone and decaying fruits and other calcium rich vegetable matter.

Considering $\mathrm{Cl}^{-}$, the concentrations detected were highest in wells 3 (20 m upslope) and 5 (180 m down slope). Table 4 shows that $\mathrm{Cl}^{-}$concentrations increase with decreasing distance from the waste dump in the up slope direction. $\mathrm{Cl}^{-}$values in well $3(297 \mathrm{mg} / \mathrm{l})$ and well $5(255 \mathrm{mg} / \mathrm{l})$ exceeded the WHO, FEPA and
USEPA standard of $200 \mathrm{mg} / \mathrm{l}$. $\mathrm{Cl}^{-}$is usually found in close association with $\mathrm{Na}^{+}$. It is leached into the environment form such household wastes as refrigerators, air conditioners and plastic foams. These materials contain $\mathrm{CF}_{2} \mathrm{Cl}_{2}$ and $\mathrm{CFCl}_{3}$, which are used as propellants in the manufactured of these products.

Cd displays a gradual increase in concentration as you move closer to the waste dump. The highest concentration value of $0.009 \mathrm{mg} / \mathrm{l}$ was detected in well 5 , down slope (Table 5). Well 4 with a concentration value of $0.004 \mathrm{mg} / \mathrm{l}$ exceeded the maximum contaminant level (m. c. I.) of $0.003 \mathrm{mg} / \mathrm{l}$ set by the World Health Organization but less than the USEPA standard of $0.005 \mathrm{mg} / \mathrm{l}$. In well 3 and 5 (Table 5), the concentration 
exceeded both the WHO and USEPA standards but less than the FEPA standards of $0.010 \mathrm{mg} / \mathrm{l}$. Incinerator ash, landfill leachate, metal plating and erosion of battery wastes contribute heavily to $\mathrm{Cd}$ load in groundwater of the area.

Considering $\mathrm{Cu}$, well 3 has the highest concentration value of $1.840 \mathrm{mg} / \mathrm{l}$ (Table 5). The value exceeded the maximum contaminant level (m. c. I.) set by FEPA (1991). Wells 4 and 5 did not show the presence of $\mathrm{Cu}$. Generally, corrosion of household plumbing systems, industrial and domestic wastes release $\mathrm{Cu}$ into the environment and groundwater. Household wastes also contain $\mathrm{Cu}$ (from copper plated materials, cooking vessels and most electrical items) that ultimately enters into groundwater.

Table 5: Heavy Metal Concentrations in Water Samples From the Study Area

\begin{tabular}{|l|l|l|l|l|l|l|l|}
\hline \multirow{3}{*}{$\begin{array}{l}\text { Up } \\
\text { slope }\end{array}$} & $\begin{array}{l}\text { Sample } \\
\text { Description }\end{array}$ & $\begin{array}{l}\mathrm{Cd} \\
(\mathrm{mg} / \mathrm{l})\end{array}$ & $\begin{array}{l}\mathrm{Cu} \\
(\mathrm{mg} / \mathrm{l})\end{array}$ & $\begin{array}{l}\mathrm{Fe} \\
(\mathrm{mg} / \mathrm{l})\end{array}$ & $\begin{array}{l}\mathrm{Hg} \\
(\mathrm{mg} / \mathrm{l})\end{array}$ & $\begin{array}{l}\text { Pb } \\
(\mathrm{mg} / \mathrm{l})\end{array}$ & $\begin{array}{l}\text { Distance } \\
\text { from dump } \\
\text { site }(\mathrm{m})\end{array}$ \\
\cline { 2 - 8 } & Well 1 & 0.000 & 0.050 & 2.300 & 0.000 & 0.000 & 160.0 \\
\cline { 2 - 8 } & Well 2 & 0.001 & 0.330 & 0.000 & 0.000 & 0.020 & 82.5 \\
\cline { 2 - 8 } & Well 3 & 0.006 & 1.840 & 2.300 & 1.247 & 0.260 & 20.0 \\
\hline \multicolumn{7}{|c|}{ Waste dump } \\
\hline \multirow{2}{*}{$\begin{array}{l}\text { Down } \\
\text { slope }\end{array}$} & Well 4 & 0.004 & 0.000 & 3.200 & 0.000 & 0.000 & 55.0 \\
\cline { 2 - 8 } & Well 5 & 0.009 & 0.000 & 4.600 & 0.000 & 0.000 & 180.0 \\
\cline { 2 - 8 } & Well 6 & 0.003 & 0.860 & 2.600 & 0.000 & 0.000 & 430.0 \\
\cline { 2 - 8 } & $\begin{array}{l}\text { Surface } \\
\text { water } \\
\text { location 1 }\end{array}$ & 0.002 & 1.380 & 0.700 & 0.000 & 0.000 & 141.0 \\
\cline { 2 - 9 } & $\begin{array}{l}\text { Surface } \\
\text { water } \\
\text { location 2 }\end{array}$ & 0.000 & 1.410 & 1.000 & 0.000 & 0.000 & 403.0 \\
\hline
\end{tabular}

The concentrations of $\mathrm{Fe}$ increase with decreasing distance from the waste dump. Besides well 2 , all other sample stations indicated the presence of $\mathrm{Fe}$ (Table 5). The concentration of $\mathrm{Fe}$ in groundwater of the study area exceeded drinking water quality standards of $1.00 \mathrm{mg} / \mathrm{l}$ and $0.300 \mathrm{mg} / \mathrm{l}$ set by FEPA (1991) and USEPA (2005) respectively. Wells 4 and 5 recorded the highest concentrations (Table 5). The high Fe content indicates that leachate from the waste dump is rich in $\mathrm{Fe}$, probably from scrap metals disposed in the dump site.

Considering $\mathrm{Hg}$ and $\mathrm{Pb}$, only well 3 indicated the presence of $\mathrm{Hg}$ while $\mathrm{Pb}$ was detected in wells 2 and 3 (Table 5). The concentration of $\mathrm{Hg}$ and $\mathrm{Pb}$ exceeded drinking water quality standard of $.0001 \mathrm{mg} / \mathrm{l}$ for $\mathrm{Hg}$ and $0.050 \mathrm{mg} / \mathrm{l}$ for $\mathrm{Pb}$ (FEPA, 1991); $0.001 \mathrm{mg} / \mathrm{l}$ for $\mathrm{Hg}$ and $0.010 \mathrm{mg} / \mathrm{l}$ for $\mathrm{Pb}(\mathrm{WHO}, 2004)$ and $0.002 \mathrm{mg} / \mathrm{l}$ for $\mathrm{Hg}$ and $0.015 \mathrm{mg} / \mathrm{l}$ for $\mathrm{Pb}$ (USEPA, 2005). Hg can get into groundwater from pesticides, electrical equipment (e.g. batteries, lamps and swatches), run-offs from landfills and croplands. $\mathrm{Pb}$ can get into leachate and subsequently groundwater from corrosion of household plumbing systems, pesticides, household paints, leachate from waste batteries, pottery, cooking vessels, landfill leachate and incinerator ash.

\section{CONCLUSIONS}

The geoelectric sections identified a maximum of four subsurface layers namely, the topsoil, the sandy clay/clayey sand unit, the weathered basement layer and the fresh basement unit. The weathered layer constitutes the main aquifer unit. This result is in agreement with earlier reports by Okhue and Olorunfemi (1991) and Olorunfemi and Okhue (1992).
Dipole-dipole resistivity structures revealed that the subsurface layers have been contaminated by leachate from the waste dump. This is indicated by the presence of contaminant plumes represented by the typically low resistivity values (< 150 ohm-m) and significant depth of over $40 \mathrm{~m}$ in some places (Figs. 5 and 6).

Hydro-chemical results confirmed the suspected subsurface and groundwater contamination from geophysical investigation results. The relatively high concentrations of total acidity and $\mathrm{Na}^{+}$suggest contamination from the waste dump. $\mathrm{Cl}^{-}$concentrations from wells 3 and 5 (297.78 $\mathrm{mg} / \mathrm{l}$ and $255.24 \mathrm{mg} / \mathrm{l}$ respectively) exceeded the FEPA USEPA, and WHO water quality standards of 1991, 2002 and 2004 respectively. Concentrations of $\mathrm{Cl}^{-}$in other wells are also relatively high. All the wells sampled indicated the presence of heavy metals ( $\mathrm{Cd}, \mathrm{Cu}, \mathrm{Fe}, \mathrm{Hg}$ and $\mathrm{Pb}$ ). $\mathrm{Fe}$ ( $2.300 \mathrm{mg} / \mathrm{l}$ wells 1 and $3 ; 3.200 \mathrm{mg} / \mathrm{l}$ well 4 and 4.600 $\mathrm{mg} / \mathrm{l}$ well 5$), \mathrm{Hg},(1.247 \mathrm{mg} / \mathrm{l}$ well 3$)$ and $\mathrm{Pb}(0.020 \mathrm{mg} / \mathrm{l}$ and $0.260 \mathrm{mg} / \mathrm{l}$ well 3 ) concentrations exceeded FEPA, USEPA and WHO water quality standards. Cd values in wells 3 and $5(0.006 \mathrm{mg} / \mathrm{l}$ and $0.009 \mathrm{mg} / \mathrm{l}$ respectively) exceeded USEPA and WHO standards of $0.003 \mathrm{mg} / \mathrm{l}$ and $0.005 \mathrm{mg} / \mathrm{l}$ respectively while $\mathrm{Cu}$ concentrations in wells $2,3,6(0.330 \mathrm{mg} / \mathrm{l}, 1.840 \mathrm{mg} / \mathrm{l}$, and $0.860 \mathrm{mg} / \mathrm{l}$ respectively) and from surface water samples for locations 1 and $2(1.380 \mathrm{mg} / \mathrm{l}$ and $1.410 \mathrm{mg} / \mathrm{l}$ respectively) exceeded the FEPA standard of 0.100 $\mathrm{mg} / \mathrm{l}$.

Generally, the presence, at relatively high concentrations, of environmental tracers (major ions, particularly $\mathrm{Na}^{+}$and $\mathrm{Cl}^{-}$) indicates that the groundwater contamination in the area is as a result of human activities. 


\section{ACKNOWLEDGMENT}

The authors are grateful to Messrs Stephen Olawore, Bayowa O.G, Momoh Lasisi and M. Afolabi for their assistance in the field work.

\section{REFERENCES}

Adepelumi, A.A, Ako, B.D and Ajayi, T.R., 2001. Groundwater contamination in the basement complex area of lle - Ife, S.W. Nigeria: A case study using the electrical resistivity geophysical method. Journal of Hydrogeology, 9, pp. 611 622.

Ajayi, T. R., 1981. On the geochemistry and Origin of the Amphibolites in Ife-llesha Area, S.W. Nigeria Journal Mining and Geology. 17(2): pp 179196.

American Public Health Association, 1992. Standard methods for the Examination of Water and Waste Water, $18^{\text {th }}$ Ed. APHA, Washington DC, pp 9-147.

Bedient, P. B., Rifai, H. S. and Newell, C. J., 1999. Groundwater Contamination: Transport and Remediation, $2^{\text {nd }}$ Edn. Prentice Hall, NJ 07458

British Drug House, 1978. Chemical Methods for Water Testing. BDH Chemical Ltd Parole pp. 42.

Elueze, A. A., 1981. Petrographic studies of metabasic and metaultramafites in relation to mineralization in Nigeria Schist Belts. Nigerian Journal of Mining and Geology 18: 198 202.

Federal Environmental Ptotection Agency, 1991. Guidelines and Standards for Environmental Pollution and Control in Nigeria. FEPA, Lagos 1235.

Ige, O. A., 1988. Mineralogical and geochemical studies of some talc-bearing ultramafic and associated mafic rocks in the Apomu and Ife-llesha areas of S.W. Nigeria. Ph.D. Thesis, University of Ife 247 pp.

Ige, O. A. and Asubiojo, O. I., 1991. Trace element Geochemistry and Petrogenesis of some metaultramafites in Apomu and Ife-llesha areas of Southwestern Nigeria, Chemical Geology, Elsevier Science Publishers B.V Amsterdam, 91(2): 19-32.

Kearey, P. and Brooks, M., 1988. An Introduction to Geophysical Exploration: Adlard and Sons Ltd., The Garden city Press Letchworth, Herts.
Klemm, D., Schneider, W. and Wagner, B., 1979. Geochemistry of the amphibolite complex and the metasedimentary sequence in the Ife-llesha area of southwest Nigeria, a Nigerian greenstone belt.10 Coll. Geol. Africaine, Montepellier, Resumes, pp 4-5

Moody, D. W., 1996. Source and extent of groundwater contamination. United States Geological Survey, NCCES Publication No. 4414.

Okhue, E. T and Olorunfemi, M. O., 1991. Electrical Resistivity Investigation of a typical basement Complex area The Obafemi Awolowo University Campus case study. Journal of Mining and Geology, 2 (2): 63-69.

Olorunfemi, M.O. and Okhue, E.T., 1992. Hydrologic and geologic significance of a geoelectrical survey at lle-lfe Nigeria. Journal of Mining and Geology 28, (1): pp. 221-229.

Rahaman, M. A., 1988. Recent advances in the study of the Basement Complex of Nigeria. In Oluyide. et. al. Precambrian Geology of Nigeria Ed. Geological Survey of Nigeria Pub. Kaduna pp. 11-44.

Samanjara, N. S. P. and Bandara, N. J. G. J., 2003. Effects of Solid Waste Landfills on Groundwater Quality: Department of Forest and Environmental Sciences, University of Sri Jayewardenepura, Sri Lanka

Scoth, J. S. and Smith, P. G., 1981. Dictionary of Waste and Water Treatment. Butteworts England. Harrol Print Ltd., Bodmin Cornwall.

Tijani, M.N., Onibalusi, S.O. and Olatunji, A.S., 2002. Hydrochemical and Environmental Impact Assessment of Orita Aperin Waste Dumpsite, South-Western Nigeria. Water Resources Journal, 13: $78-85$.

United States Environmental Protection Agency, 2002. List of Drinking Water Contaminants and m.c.l, EPA 816-02-013, July 2002.

United States Geological Survey, 2005. Water Science for Schools, Groundwater Quality, USGS, August 2005.

World Health Organization, 2004. WHO's Guidelines for Drinking Water Quality. Lenntech Water Treatment and Air Purification. Holding Rotterdamseweg. 